УДК 577.27

A.I. FLYAK ${ }^{1}$, M.V. PAVLOVA ${ }^{1}$, P.V. GILCHUK ${ }^{2}$

${ }^{1}$ National Taras Shevchenko University of Kyiv, Ukraine

${ }^{2}$ Institute of Molecular Biology and Genetics NAS of Ukraine, Kyiv E-mail: gilchuk@ukr.net

E-mail: flyaka@mail.ru

\section{IN SILICO ANALYSIS OF THE STRUCTURE OF VARIABLE DOMAINS OF MOUSE SINGLE-CHAIN ANTIBODIES SPECIFIC TO THE HUMAN RECOMBINANT INTERFERON $\beta 1 b$}

Introduction. An important feature of antibodies is the extraordinary variability of their antigen-binding sites ensuring specific and high-affinity interaction with the target antigen. Due to their high binding ability antibodies are of great value as unique molecular probes for fundamental research, as well as in biotechnology and medicine.

Modern gene manipulation techniques enable generation of recombinant antibody fragments single-chain antibodies (ScFv's), as well as their production in Escherichia coli cells. ScFv's are obtained by translating DNA sequences of immunoglobulin heavy-chain $\left(\mathrm{V}_{\mathrm{H}}\right)$ and light-chain $\left(\mathrm{V}_{\mathrm{L}}\right)$ variable domains joined in one gene [1]. The approaches to construction and selection of combinatorial cDNA libraries of $V$-genes in vitro allow isolation of $\mathrm{ScFv}$ with desired affinity and specificity, bypassing the stages of traditional hybridoma technology $[2,3]$.

The diversity of antigen-binding regions of antibody variable domains is defined by the structure of the underlying encoding gene elements. The genes of the light chain result from recombination of one variable $(V)$ and joining $(J)$ gene segments. Recombination events in the heavy chain are more complex due to the presence of an additional $D$ segment. One of the mechanisms of increasing diversity is incorporation of n-nucleotides (nontemplated nucleotides) at the gene segment joint site [4]. Later on, the DNA sequences of variable (V) domains are affected by the influence of somatic hypermutations taking place during the affinity maturation of B-cells. The highest rate of point mutations occurs at complementarity determining regions (CDR), as opposed to framework regions (FR) where the rate is relatively low.

Up to date, there have been created a number of databases of antibody germline gene segments, as well as software for identification of $V-, D_{-}$, and $J_{-}$ gene segments, n-nucleotides, CDR and FR segments, mutation rates, etc. A detailed analysis of nucleotide and aminoacid sequences of antibody $\mathrm{V}$-domains is needed for a number of reasons. First of all, it allows determining the degree of conformational uniqueness of the antigen binding site of the obtained antibodies, which can be achieved by comparing their aminoacid sequences with yet known immunoglobulin sequences. Second, while analyzing multiple antibody variants against one antigen (a panel of antibodies), determining $V-, D_{-}$, and $J$-gene segments, n-nucleotides, and mutations rates enables evaluation of the panel's heterogene- 
ity and proper choice of the most promising candidate molecules for further work. However, what makes most sense is that determining CDR and FR regions of antibody V-domains is an indispensable prerequisite for beginning manipulations to improve their functional characteristics, such as decreasing immunogeneity (in case of humanization), or DNA combinatorial mutagenesis - an in vitro technique used to increase affinity and stability of obtained antibodies.

The most widespread strategy for humanization is grafting of CDR regions of an antigen-specific monoclonal antibody with FR regions of selected V-domains of human antibodies [5]. An example of the practical value of the abovementioned technology is the fact that today out of 30 monoclonal antibody-based drugs approved by FDA (Food and Drug Administration, USA) for clinical application over one third are humanized antibodies [6].

The core of the combinatorial mutagenesis technique lies in directed randomization of certain regions of $\mathrm{V}$-domains using a set of oligonucleotides with degenerate codons. Randomization targets may include CDR3 regions of $\mathrm{V}_{\mathrm{H}}$ and $\mathrm{V}_{\mathrm{L}}$ domains [7], all six CDRs [8], or certain aminoacids of Vdomains [9].

The indicated method is particularly valuable while working with naïve and synthetic libraries of antibody fragments («single-pot» antibody libraries), as combined with the phage display it allows isolation of antibody molecule variants with improved characteristics of expression in bacteria, prolonged stability in blood stream, as well as exclusively high affinity to the target antigen [8].

Our previous work resulted in obtaining and characterization of a panel of mouse ScFv's against rhIFN- $\beta 1 b$. The goal of the present work was sequencing and in silico analysis of the primary structure of the ScFv's obtained.

Materials and methods. DNA sequencing was carried out using the automatic DNA sequencer IBI Prism 3130 (Applied Biosystems, USA). We sequenced DNA (approx. $1000 \mathrm{bp}$ ) obtained by polymerase chain reaction (PCR) using the following primers: pCANTAB-R1 5'-d [CCATGATTACGCCAAGCTTTGGAGCC]-3', pCANTAB-R2 5'-d [CGATCTAAAGTTTTGTCGTCTTTCC]-3' and preliminary obtained recombinant phagemids of the corresponding bacterial clones as matrices. For sequencing, we used the following primers:
pCANTAB 5-S3: 5'-d [GGTTCAGGCGGAGGTGGCTCTGG] - 3';

pCANTAB 5-S4: 5'-d [CCAGAGCCACCTCCGCCTAACC] -3

pCANTAB 5-S1: 5'-d [CAACGTGAAAAAATTATTATTCGC] - 3';

pCANTAB 5-S6: 5'-d [GTAAATGAATTTTCTGTATGAGG] -3 .

Sequencing results were processed and interpreted with assistance of Vector NTI Advance 10 (Invitrogen, USA) software. The level of homology between $\mathrm{ScFv}$ nucleotide sequences was determined using ClustalW2 software (http://www.ebi.ac.uk / Tools/clustalw2/) [10]. Identification of $V$-, $D$-, and $J$-gene segments encoding $\mathrm{ScFv}$ specific to rhIFN$\beta 1 b$ and rhIFN- $\alpha 2 b$, was assisted by Somatic Diversification Analysis (SoDA) software (http:// dulci.org/soda/) [11]. All gene segment names are used in accordance with the standardization rules of the international information system IMGT [12]. Additional n-nucleotides and mutations that occurred during antibody affinity maturation were determined by comparing the target sequences with respective germline gene sequences of $V-, D-$, and $J$-gene segments from the IMGT database. CDR and FR regions were determined with the help of SoDA software in accordance with the criteria developed by IMGT. In view of this, we labeled the indicated regions as CDR-IMGT and FRIMGT [13].

Search of closest homologs for the aminoacid sequences was performed using IgBLAST software (http://www.ncbi.nlm.nih.gov/igblast/) of the immunoglobulin $\mathrm{V}$ region sequences database of the National Center for Biotechnology Information (NCBI), USA. First, we looked for homologs to a whole $\mathrm{ScFv}$ sequence, and then separately for variable domains $\mathrm{V}_{\mathrm{H}}$ and $\mathrm{V}_{\mathrm{L}}$. For sequences with highest homology, we built multiple alignments using Vector NTI Advance 10 software.

Results and Discussion. In previous publications, we described generation of an immune combinatorial cDNA library of mouse immunoglobulin $V$-genes and isolation of a panel of single-chain antibodies specific to rhIFN- $\beta 1 b[14,15]$. For some isolated ScFv's such characteristics as binding specificity to native and denatured antigen, level of production in $E$. coli by secretion, stability etc. were determined. An interesting point was that some producers randomly selected out of more 
$\mathrm{ScFv}$ (naïve) group 3

$\mathrm{ScFv}(\mathrm{IFN} \alpha)$ group 4

A dendrograme reflecting the homology between nucleotide sequences of ScFv's carried out using ClustalW2 software. $\# 1$, \#2, \#4, \#11 are ScFv's isolated from an immune cDNA library and specific to rhIFN- $\beta 1 b$; ScFv (naïve) ScFv's isolated from a naïve cDNA library and specific to rhIFN- $\beta 1 b$; ScFv (IFN $\alpha)-$ ScFv's specific to rhIFN- $\alpha 2 b$

than 30 isolated positive clones invariably differed between each other in the production level of the ScFv's $(0.6$ to $3.5 \mathrm{mg} / \mathrm{L})$ and their accumulation rate, ScFv's sensitivity to proteolysis, ScFv's affinity $\left(1.96 \cdot 10^{-8} \mathrm{M}\right.$ to $\left.1.69 \cdot 10^{-9} \mathrm{M}\right)$, and ScFv's binding specificity with native and denatured rhIFN$\beta 1 b[15]$.

In many experiments dedicated to study expression of $\mathrm{ScFv}$ in E. coli, the influence of the primary structure of variable domains on their production rate has been shown. It is also known that replacement of at least one aminoacid in CDR regions may have dramatic influence on antibody affinity and specificity [16]. The differences in production rates in bacterial cells, as well as various antigenbinding characteristics of some ScFv's from the obtained panel seem to suggest nonidentity of the primary structure of their variable domains. To test this suggestion we sequenced the DNA of all
ScFv's identified as positive in the reaction of binding to rhIFN- $\beta 1 \mathrm{~b}$. Among the 12 analyzed sequences isolated from different producers, we revealed four DNA variants that encode $\mathrm{ScFv}$ with different primary structure - \#1, \#2, \#4, \#11. These were the sequences we selected for further analysis.

DNA homology of ScFv's was estimated using ClustalW2 software [10]. For analysis, we used the four sequences of ScFv's against rhIFN- $\beta 1 \mathrm{~b}$ isolated from the immune library, a sequence of $\mathrm{ScFv}$ against rhIFN- $\beta 1 \mathrm{~b}$ preliminarily obtained from a naïve library [15], as well as a sequence of ScFv's against rhIFN- $\alpha 2 b$ [17]. According to the criterion of homology for their DNA, all six ScFv's were provisionally divided into four groups (Figure).

Mapping structurally and functionally valuable regions within antibody variable domains is an important task. Using SoDA software, we identified $V$-, $D$-, and $J$-gene segments, n-nucleotides, as well as mutations that occurred during affinity maturation of respective sequences in vivo [11]. Armed with this same software we identified the boundaries and lengths of all CDR-IMGT and FR-IMGT. The results are summarized in Table 1.

It was determined that the DNA sequences of $\mathrm{V}_{\mathrm{H}}$ and $\mathrm{V}_{\mathrm{L}}$ domains of the ScFv's from the first group (\#1, \#4) were formed by germline gene segments IGHV1-26 and IGKV3-2; the sequences

ScFv's variable domain DNA analysis carried out using SoDA software

Table 1

\begin{tabular}{|c|c|c|c|c|c|c|c|c|c|c|c|}
\hline Group & $\mathrm{ScFv}$ & \begin{tabular}{c|}
$\mathrm{V}-$ \\
domain
\end{tabular} & $\begin{array}{c}V \text {-gene } \\
\text { segment }\end{array}$ & $\begin{array}{c}\text { Number } \\
\text { of V- } \\
\text { mutations }\end{array}$ & 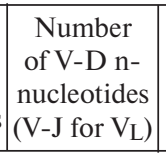 & $\begin{array}{c}D \text {-gene } \\
\text { segment }\end{array}$ & $\begin{array}{c}\text { Number } \\
\text { of D- } \\
\text { mutations }\end{array}$ & $\begin{array}{c}\text { Number } \\
\text { of D-J n- } \\
\text { nucleotides }\end{array}$ & $\begin{array}{c}J \text {-gene } \\
\text { segment }\end{array}$ & $\begin{array}{c}\text { Number of } \\
\mathrm{J} \text {-muta- } \\
\text { tions }\end{array}$ & $\begin{array}{c}\mathrm{CDRH} 3 \\
\text { region } \\
\text { length }\end{array}$ \\
\hline \multirow[t]{4}{*}{1} & 1 & $\mathrm{H}$ & IGHV1-26 & 23 & 3 & \multirow[t]{2}{*}{ IGHD4-1 } & \multirow[t]{2}{*}{0} & \multirow[t]{2}{*}{2} & IGHJ2 & 3 & 6 \\
\hline & & $\mathrm{L}$ & IGKV3-2 & 5 & 0 & & & & IGKJ1 & 4 & 9 \\
\hline & 4 & $\mathrm{H}$ & IGHV1-26 & 24 & 3 & \multirow[t]{2}{*}{ IGHD4-1 } & \multirow[t]{2}{*}{0} & \multirow[t]{2}{*}{4} & IGHJ1 & 2 & 6 \\
\hline & & $\mathrm{L}$ & IGKV3-2 & 9 & 0 & & & & IGKJ1 & 2 & 9 \\
\hline \multirow[t]{4}{*}{2} & 2 & $\mathrm{H}$ & IGHV1-67 & 15 & 2 & \multirow[t]{2}{*}{ IGHD4-1 } & \multirow[t]{2}{*}{0} & \multirow[t]{2}{*}{3} & IGHJ4 & 4 & 6 \\
\hline & & $\mathrm{L}$ & IGKV3-2 & 8 & 4 & & & & IGKJ5 & 2 & 9 \\
\hline & 11 & $\mathrm{H}$ & IGHV1-67 & 18 & 4 & \multirow[t]{2}{*}{ IGHD3-2 } & \multirow[t]{2}{*}{1} & \multirow[t]{2}{*}{0} & IGHJ1 & 2 & 6 \\
\hline & & $\mathrm{L}$ & IGKV3-2 & 5 & 4 & & & & IGKJ5 & 2 & 9 \\
\hline \multirow[t]{2}{*}{3} & $\mathrm{ScFv}$ & $\mathrm{H}$ & IGHV1S128 & 10 & 2 & \multirow[t]{2}{*}{ IGHD2-1 } & \multirow[t]{2}{*}{1} & \multirow[t]{2}{*}{2} & IGHJ2 & 4 & 13 \\
\hline & (naive) & $\mathrm{L}$ & IGKV17-121 & 0 & 2 & & & & IGKJ1 & 2 & 9 \\
\hline \multirow[t]{2}{*}{4} & $\mathrm{ScFv}$ & $\mathrm{H}$ & IGHV14-3 & 6 & 3 & \multirow[t]{2}{*}{ IGHD1-1 } & \multirow[t]{2}{*}{0} & \multirow[t]{2}{*}{0} & IGHJ4 & 4 & 10 \\
\hline & $(\mathrm{IFN} \alpha)$ & $\mathrm{L}$ & IGKV8-19 & 11 & 4 & & & & IGKJ1 & 2 & 9 \\
\hline
\end{tabular}

Note. All $V$-, $D$-, and $J$-gene segments' names are in accordance with the IMGT standardization rules [12]. 
of the second group (\#2, \#11) were formed by the segments IGHV1-67 and IGKV3-2; those of the third group - by IGHV1S128 and IGKV17-121; and those of the fourth group - by IGHV14-3 and IGKV8-19, respectively. The results suggest that all the $V$-gene segment of the four ScFv's from the panel isolated from the immune combinatorial cDNA library belong to the first and the third IMGT subgroup, respectively [12]. The length of
CDRH3-IMGT and CDRL3-IMGT regions of the four ScFv's isolated from the immune library was 6 and 9 aminoacid residues, respectively. The CDRH3-IMGT region of $\mathrm{ScFv}$ isolated from the naïve library turned out to be longer and consisted of 13 aminoacid residues (Table 1 ).

One of $V$-genes' diversity sources are somatic hypermutations appearing in vivo during the processes known as B-cell affinity maturation. Random

Table 2

Alignment of CDR-IMGT regions for $V_{H}$ and $V_{L}$ of obtained ScFv's with nearest $V$-domain sequences ${ }^{1}$

\begin{tabular}{|c|c|c|c|c|}
\hline Group & № of sequence & CDR1 & CDR2 & CDR3 \\
\hline \multicolumn{5}{|c|}{ Regions for $\mathrm{V}_{\mathrm{H}}$} \\
\hline \multirow[t]{6}{*}{1} & 1 & GYSETGYP & INPYNGGT & ARF $=--------P A--Y$ \\
\hline & 4 & $* * * * * * * *$ & $* * * * * * * *$ & $* * *---------* * *--*$ \\
\hline & $\mathrm{AAO} 85280^{2}$ & $* * * * * * * \mathrm{~T}$ & $* * * * * * * *$ & $* * Y P Q F I T T A R R Y * M D *$ \\
\hline & AA0852842 & $* * * * * * * \mathrm{~T}$ & $* * * * * * * *$ & $* * A A G---I L R L R D F D *$ \\
\hline & AA0852862 & $* * * * * * * \mathrm{~T}$ & $* * * * * * * *$ & $* * A A G---I L R L R D F D *$ \\
\hline & ABK599112 & $* * * * * * * \mathrm{~T}$ & $* * * * * * * *$ & $* *$ DVRG------AWFA $*$ \\
\hline \multirow[t]{6}{*}{2} & 2 & GYTETDYA & ISTYSGDT & ARP-------- $P N--Y$ \\
\hline & 11 & $* * * * * * * *$ & $* * * * * * \mathrm{~N} *$ & $* * *--------* A--*$ \\
\hline & AAF 814172 & $* * * * * * * *$ & $* * * * \mathrm{~N} * \mathrm{~N} *$ & $* * Y Y G-----N Y F D *$ \\
\hline & CAA 749172 & $* * \mathrm{~K} * * * * *$ & $* * * * Y * * *$ & *LLRP--ー------FA* \\
\hline & CAA749232 & $* * \mathrm{~K} * * * * *$ & $* * * * Y * * *$ & *LLRP--ー------FA* \\
\hline & AAA832672 & $* * * * * S * \omega$ & $* N P S N * R *$ & $* * G G V Y Y-D L Y Y Y A L D Y$ \\
\hline \multirow[t]{2}{*}{3} & ScFv(naïve) & GYTF TSYR & INPSNGRT & ARSYYG----NFYYFDY \\
\hline & AAA 832672 & $* * * * * * * \omega$ & $* * * * * * * *$ & $* * G G V Y Y-D L Y Y * A L * *$ \\
\hline \multirow[t]{2}{*}{4} & $\operatorname{ScFv}(\operatorname{IFNa})$ & GFNIKDTF & IDPANGYT & ASR-------VDYAMDY \\
\hline & AAA $16583^{2}$ & $* * * * * * * Y$ & $* * * * * * \mathrm{~N} *$ & $* \mathrm{R} *------\mathrm{A} S * * * * *$ \\
\hline \multicolumn{5}{|c|}{ Regions for $V_{\mathbf{L}}$} \\
\hline \multirow[t]{6}{*}{1} & 1 & ESVDNYGIS--E & AAS & $\underline{\text { QQSKEVPWT }}$ \\
\hline & 4 & $* * * * * * * * *--*$ & $* * *$ & $* * G * * * * * *$ \\
\hline & $A B C 55323^{2}$ & $* * * * * * * * *--*$ & $* * *$ & $* * * * * * * Y *$ \\
\hline & IHOD_A2 & $* * * * * * * * *--*$ & $* * *$ & $* * * * * * * \mathrm{~L} *$ \\
\hline & AAA $39015^{2}$ & $* * * * * * * * *--*$ & $* * *$ & $* * * * * * * * *$ \\
\hline & s099692 & $* * * * * * * * *--*$ & $* * *$ & $* * G * * I * Y *$ \\
\hline \multirow[t]{6}{*}{2} & 2 & ESVDKYGIS- - & $\underline{A A S}$ & $\underline{\text { QQSKEVPWT }}$ \\
\hline & 11 & $* * * * N * * * *--*$ & $* * *$ & $* * * * * * * * *$ \\
\hline & P016562 & $* * * * N S * * *--*$ & $* * *$ & $* * * * * * * * *$ \\
\hline & A AB $30460^{2}$ & $* * * * \mathrm{~N} * * * *--*$ & $* * *$ & $* * * * * * * * *$ \\
\hline & CAA801072 & $* * * * N * * * *--*$ & $* * *$ & $* * * * * * * \mathrm{P} *$ \\
\hline & P016542 & $* * * * N * * * *--*$ & $* * *$ & $* * * * * * * * *$ \\
\hline \multirow[t]{2}{*}{3} & ScFv (naïve) & TDID D $-\cdots---$ & EGN & LQSDNLPLP \\
\hline & AAZ503752 & $* * * * * *-----$ & $* * *$ & $* * * * * * * * \mathrm{~T}$ \\
\hline \multirow[t]{2}{*}{4} & $\operatorname{ScFv}(\operatorname{IFNa})$ & QSLLNSGNQKNY & WAS & QNDYSYPLT \\
\hline & AAA $38730^{2}$ & $* * * * * * * * * * * *$ & $* * *$ & $* * * * * * * * *$ \\
\hline
\end{tabular}

Note. ${ }^{1}$ - search of closest homologs for the aminoacid sequences was performed using IgBLAST software of the immunoglobulin V-region sequences database of the NCBI; 2 - the sequence number corresponds to the number in GenBank; «_» indicated amino acids common for CDR-IMGT regions of ScFv's of groups 1 and 2; * indicated the same amino acids within each $\mathrm{ScFv}$ group; «-» - denotes the absence of an aminoacid at this position. 
aminoacid replacements affect the antigen-binding properties of antibodies, which results from local changes in variable domain conformation as well as changes in quantity/quality of functional groups in aminoacid residues that directly contact with antigen [8]. For $V-, D$-, and $J$-gene segments of $V$ domains of the studied ScFv's, we have determined the respective mutation rates - the absolute quantity of nucleotide substitutions deduced from juxtaposing the sequences in question against the sequences of the identified germline gene segments (Table 1). It has been shown that the indicated rates for $V$-gene segments of ScFv's \# 1 and \#4 (group 1) is higher compared to that of $\mathrm{ScFv} \# 2$ and \#11 (group 2). The fact that the absolute mutation rate for $V$-gene segments of $\mathrm{ScFv}$ isolated from the naïve library ( $\mathrm{ScFv}$ (naïve)) is the lowest for all analyzed sequences was an expected result (Table 1).

Our search results for similar experimental works suggest that a panel of ScFv's against rhIFN- $\beta 1 b$ has been obtained for the first time. Taking into account this fact, as well as the methodological novelty of the generation and selection scheme for the respective combinatorial library of $V$-genes [14], it was important to estimate the degree of uniqueness of the antigen-binding site of the isolated ScFv's. It is common knowledge that the specificity of the «antigen-antibody» interaction is, first of all, determined by the primary structure of the CDR regions which aminoacids are responsible for direct contact with the antigen. Exposed on the surface of V-domains, CDR regions are spatially accessible for interaction with the antigen and form canonical loop-like structures. Among other CDRs, CDRH3 is the most variable in length and aminoacid composition, and plays a key role in antigen recognition [16].

Using IgBLAST software of the NCBI immunologic sequence database we performed a search for closest homologs separately for the aminoacid sequences of both $\mathrm{V}$-domains and the whole sequence of ScFv. Multiple alignment of the obtained ScFv's with their closest homologs from the database revealed differences in the primary structures of $\mathrm{V}_{\mathrm{H}}$ and $\mathrm{V}_{\mathrm{L}}$ in aminoacid substitutions at certain positions (results not presented), while the structure of CDRH3-IMGT turned out to be absolutely unique (Table 2). Uniqueness of the primary structure of CDRH3-IMGT as well as the absence of antibody sequences with homologous
V-domains in the database, suggests that the antigen-binding site of the four isolated $\mathrm{ScFv}$ is conformationally unique, and the sequences are novel.

Comparative analysis of the CDRH3-IMGT regions of these ScFv's has revealed a conservative motif AR_P_Y with substitutions at positions 120 $(\mathrm{F} / \mathrm{P})$ and $122(\mathrm{~A} / \mathrm{N})$. Substantial differences were observed in CDRH1-IMGT and CDRH2-IMGT (Table 2). It is known from published data that only a slight part of the aminoacid residues of CDRs contribute significantly to the free energy $(\triangle \mathrm{G})$ of interaction with the antigen [18]. Some publications show a key role for aminoacids located in the central part of CDRH3, while the flanking aminoacids mostly stabilize the formed complex $[8,16,19]$. It is a matter of fact that single aminoacid substitutions in the central part of CDRH3 may dramatically affect antibody's affinity and specificity. The aforementioned substitutions in CDRIMGT may explain the differences in the panel's ScFv's antigen-binding properties studied in the previous work [15]. We suppose the identified amino acid residues are promising targets for further ScFv's mutagenesis.

It seemed interesting to compare the structure of CDRH3-IMGT regions of ScFv's specific to antigens rhIFN- $\beta 1 b$ and rhIFN- $\alpha 2 b$ that are structural and functional homologs. For comparison, we used the sequences of two highly specific ScFv's isolated from different independently generated immune libraries. For all six CDR-IMGT of ScFv's that were compared, we observed differences in the amino acid composition to the extant of individual substitutions, while CDRL1-IMGT and CDRH3-IMGT also differed by the length of the loop (Table 2, sequences \# 1 and $\operatorname{ScFv}(\operatorname{IFN} \alpha)$ ). Taking into account the absence of crosslink binding between these ScFv's and the respective antigens, which we had shown before using ELISA, we may suppose their interaction with different epitopes.

Conclusion. Within a panel of ScFv's against rhIFN- $\beta 1 b$ isolated from an immune combinatorial cDNA library of mouse genes, we have revealed four sequences with different primary structures. In silico analysis has identified structurally and functionally important regions in the variable domains of the obtained ScFv's. It has been shown that the structure of the antigen-binding site of the four isolated ScFv's is unique, and the sequences themselves are new. 
Authors are grateful to staff of Department of Functional Genomics of Institute of Molecular Biology and Genetics NAS of Ukraine for DNA sequencing.

\author{
А.И. Фляк, М.В. Павлова, П.В. Гильчук \\ IN SILICO АНАЛИЗ СТРУКТУРЫ \\ ВАРИАБЕЛЬНЫХ ДОМЕНОВ \\ ОДНОЦЕПОЧЕЧНЫХ АНТИТЕЛ МЫШИ, \\ СПЕЦИФИЧНЫХ К РЕКОМБИНАНТНОМУ \\ ИНТЕРФЕРОНУ $\beta 1 \mathrm{~b}$ ЧЕЛОВЕКА
}

Проведен in silico анализ структуры последовательностей ДНК, кодирующих специфические к интерферону $\beta 1 b$ и $\alpha 2 b$ человека (rhIFN- $\beta 1 b$, rhIFN- $\alpha 2 b)$ одноцепочечные антитела ( $\mathrm{ScFv}$ - single-chain Fv): определены $V, D$ и $J$ сегменты, границы антиген-связывающих (CDR) и каркасных (FR) участков, n-нуклеотиды, а также величина мутационных процессов, которые имели место при аффинном дозревании последовательностей in vivo. Для представителей панели $\mathrm{ScFv}$ против rhIFN- $\beta 1 b$, изолированных из иммунной комбинаторной библиотеки кДНК $V$-генов, показана уникальность участка CDRH3 как по длине, так и по аминокислотному составу. Множественное выравнивание с ближайшими гомологами базы данных NCBI показало, что полученные нами последовательности $\mathrm{ScFv}$ являются новыми.

\section{А.І. Фляк, М.В. Павлова, П.В. Гільчук \\ IN SILICO АНАЛІЗ СТРУКТУРИ ВАРІАБЕЛЬНИХ ДОМЕНІВ ОДНОЛАНЦЮГОВИХ АНТИТІЛ МИШІ, СПЕЦИФІЧНИХ ДО РЕКОМБІНАНТНОГО ІНТЕРФЕРОНУ $\beta 1 \mathrm{~b}$ ЛЮДИНИ}

Проведено in silico аналіз структури послідовностей ДНК, які кодують специфічні до рекомбінантного інтерферону $\beta 1 \mathrm{~b}$ та $\alpha 2 \mathrm{~b}$ людини (rhIFN- $\beta 1 b$, rhIFN$\alpha 2 b)$ одноланцюгові антитіла ( $\mathrm{ScFv}$ - single-chain Fv): визначено $V$-, $D$ - та $J$-генні сегменти, межі антигензв'язувальних (CDR) та каркасних (FR) ділянок, nнуклеотиди, а також величину мутаційних процесів, що мали місце при афінному дозріванні даних послідовностей in vivo. Для представників панелі ScFv проти rhIFN- $\beta 1 \mathrm{~b}$, ізольованих з імунної комбінаторної бібліотеки кДНК $V$-генів, показано унікальність ділянки CDRH3 як за довжиною, так і за амінокислотним складом. Множинне вирівнювання 3 найближчими гомологами бази даних NCBI показало, що одержані нами послідовності ScFv є новими.

\section{REFERENCES}

1. Bird R.E., Hardman K.D., Jacobson J.W., Johnson S., Kaufman B.M., Lee S.M., Lee T., Pope S.H., Riordan G.S.,
Whitlow M. Single-chain antigen-binding proteins // Science. - 1988. - 242, № 4877. - P. 423-426.

2. Hoogenboom H.R. Overview of antibody phage-display technology and its applications // Meth. Mol. Biol. 2002. - 178, № - P. 1-37.

3. Bradbury A., Marks J.D. Antibodies from Phage antibody libraries // J. Immunol. Meth. - 2004. - 290, № $1 / 2$. - P. 29-49.

4. Kepler T.B., Borrero M., Rugerio B., McCray S.K., Clarke S.H. Interdependence of N nucleotide addition and recombination site choice in $\mathrm{V}$ (D) $\mathrm{J}$ rearrangement // J. Immunol. - 1996. - 157, № 10. - P. 44514457.

5. Jones P.T., Dear P.H., Foote J., Neuberger M.S., Winter $G$. Replacing the complementarity-determining regions in a human antibody with those from a mouse // Nature. - 1986. - 321, № 6069. - P. 522-525.

6. Dubel $S$. Recombinant therapeutic antibodies // Appl. microbiol. biotechnol. - 2007. - 74, № 4. - P. 723729.

7. Knappik A., Ge L., Honegger A., Pack P., Fischer M., Wellnhofer G., Hoess A., Wolle J., Pluckthun A., Virnekas $B$. Fully synthetic human combinatorial antibody libraries (HuCAL) based on modular consensus frameworks and CDRs randomized with trinucleotides // J. Mol. Biol. - 2000. - 296, № 1. - P. 57-86.

8. Rothe C., Urlinger S., Lohning C., Prassler J., Stark Y., Jager U., Hubner B., Bardroff M., Pradel I., Boss M., Bittlingmaier R., Bataa T., Frisch C., Brocks B., Honegger A., Urban M. The human combinatorial antibody library HuCAL GOLD combines diversification of all six CDRs according to the natural immune system with a novel display method for efficient selection of high-affinity antibodies // J. Mol. Biol. - 2008. 376. - P. 1182-1200.

9. Sidhu S.S., Li B., Chen Y., Fellouse F.A., Eigenbrot C., Fuh $G$. Phage-displayed antibody libraries of synthetic heavy chain complementarity determining regions // J. Mol. Biol. - 2004. - 338, № 2. - P. 299-310.

10. Li K.B. ClustalW-MPI: ClustalW analysis using distributed and parallel computing // Bioinformatics. 2003. - 19, № 12. - P. 1585-1586.

11. Volpe J.M., Cowell L.G., Kepler T.B. SoDA: implementation of a 3D alignment algorithm for inference of antigen receptor recombinations // Bioinformatics. 2006. - 22, № 4. - P. 438-444.

12. Giudicelli V., Lefranc M.P. Ontology for immunogenetics: the IMGT-ONTOLOGY // Bioinformatics. 1999. - 15, № 12. - P. 1047-1054.

13. Lefranc M.P., Pommie C., Ruiz M., Giudicelli V., Foulquier E., Truong L., Thouvenin-Contet $V$., Lefranc $G$. IMGT unique numbering for immunoglobulin and $\mathrm{T}$ cell receptor variable domains and Ig superfamily Vlike domains // Dev. Comp. Immunol. - 2003. - 27, № 1. - P. 55-77. 
14. Pavlova M.V., Gilchuk P.V., Pokholenko Ya.O., Nikolayev Yu.S., Kordium V.A. Construction and characterization of immune cDNA combinatorial antibody library of mouse variable immunoglobuline genes // Cytology and Genetics. - 2008. - 42, № 2. - P. 10-15.

15. Pavlova M.V., Nikolayev U.S., Irodov D.M., Kordium V.A., Gilchuk P.V. Characterization of a panel of mouse single-chain antibodies against human recombinant interferon $\beta 1 \mathrm{~b} / /$ Cytology and Genetics. - 2008. - 42, № 4. - P. 3-11.

16. Xu J.L., Davis M.M. Diversity in the CDR3 region of V $(\mathrm{H})$ is sufficient for most antibody specificities // Immunity. - 2000. - 13, № 1. - P. 37-45.

17. Okunev O.V., Gilchuk P.V., Irodov D.M., Deryabina O.G.
Obtaining and characterization of the single chain antibodies against human alpha2b-interferon // Ukrainan Biochemical Journal. - 2005. - 77, № 5. - P. 106115.

18. Kelley R.F., O'Connell M.P. Thermodynamic analysis of an antibody functional epitope // Biochemistry. 1993. - 32, № 27. - P. 6828-6835.

19. Honegger $A$. Engineering antibodies for stability and efficient folding // Handbook of Experimental Pharmacology. Therapeutic Antibodies / Eds Y. Chernajovsky, A. Nissim - Heidelberg : Springer Berlin, 2008. - Vol. 181. - P. 47-68.

Received 10.07.08 